Prof. Hensen (Kiel) gave a demonstration on an acoustic apparatus, the result of which was to show that the view of Helmholtz, that the vowels owe their special quality to overtones produced in the mouth and adjoining cavities, requires modification ; this, in the author's opinion, is impossible.

Friday Afternoon.-Presidents, Profs. Richet and Cybulsky. Dr. Sherrington (London) gave a demonstration on eye movements.

I)r. Lanz (Bern) read a paper on the effect of removal of the thyroid, and of thyroid-feeding in normal animals. Among many interesting results, the author found that thyroidectomised hens either lost their power of laying eggs, or laid very small and ill-formed ones. On the other hand, hens fed with thyroids (30 grms. per diem) had their egg-laying power greatly in creased. In some animals the anthor found that the administration of large quantities of thyroid gland caused an arrest of growth.

Dr. Phisalix (Paris) showed that the blood of the salamander rendered animals immune to curare. This immunity in the case of the frog and pigeon lasts several days.

Prof. Mosso (Turin) read a paper on the effect of rarefied air upon man and apes. The author's researches on man were made on Mount Rosa, at a height of 5600 metres. The author showed that at this altitude the respiratory exchange is diminished; his observations were made under conditions of absolute rest, mostly during sleep. In the explanation of these phenomena the author thinks more attention should be paid to the diminution of $\mathrm{CO}_{2}$. He describes them under the name of Akapnia $(\kappa a \pi \nu o s=$ smoke). Mosso further described an experiment which he made upon a monkey. He subjected this animal to an atmosphere of pure $O$ at a low pressure; he observed under these conditions the phenomena of mountain-sickness (Bergkrankheit) even when the pressure of the $\mathrm{O}$ exceeded the partial pressure of this gas in the atmosphere under ordinary circumstances. The author concluded that the two main factors which come into play at high altitudes are (I) the diminution of $\mathrm{CO}_{2}$ in arterial blood; (2) the physical effect of low pressure on the nervous system.

F. W. TUNNiClifFe.

\section{CORRESPONDING SOCIETIES OF THE BRITISH ASSOCIATION.}

THE first meeting of the Conference took place on Thursday, September 12, the second on Tuesday, September 17, at the Co-operative Hall, at $3.30 \mathrm{p} . \mathrm{m}$.

At the first meeting, the Corresponding Societies Committec was represented by Mr. G. J. Symons (Chairman), Prof. R. Meldola, Mr. J. Hopkinson and Mr. T. V. Holmes (Secretary). The Chairman opened the proceedings with an address.

On the conclusion of the address, Mr. T. V. Holmes made a few remarks with regard to the list of papers read before the various Corresponding Societies, and appended to the Report of the Corresponding Societies Committee. He hoped that the Secretaries of the Corresponding Societies, in preparing their lists, would be careful to group papers, which from their titles might belong to either of two Sections, with that to which they had most affinity. It was also most desirable that the names of papers sent in should not turn out to be mere popular lectures, but should contain something original. It had sc..netimes happened that on wishing to refer to some paper on the list sent in by some Society, in order to ascertain its true character, it could not be found on their shelves at Burlington House. In future no paper could be placed on the list published by the British Association unless it was on their book-shelves.

Captain Elwes (Dorset) laid upon the table a paper on the rainfall in the county of Dorset, which had been compiled by a member of the Dorset Natural History and Antiquarian Field Club, Mr. Eaton. It was a most careful piece of work, and was illustrated by maps and diagrams.

Mr. Hopkinson said that about twenty years ago he began to note the rainfall of Hertfordshire with about twenty observers. Last year the record he published contained the monthly returns from forty observers. He trusted that delegates would preserve any early meteorological records they might find.

Mr. De Rance remarked that the increasing usefulness of local societies was shown by the fact that two British Association Committees had ceased to exist, that on coast erosion, and that on the circulation of underground waters, on account of the admirable way in which their work had been taken up by the local societies.

His Honour Deemster (Gill said that the subject of coast erosion had been taken up by a Committee of the Legislature of the Isle of Man, but their investigations were not yet complete. They had found that for some twenty miles on the west, the north-west and the north, there had been a destruction of land of about twenty acres to the mile within the last fifty or sixty years. The meteorology of the Isle of Man was also being well looked after.

Mr. Sowerbutts asked whether it was desirable that the Manchester Geographical Society should collect the results of observations at their local observatories, and forward them to the Meteorological Society; and the Chairman replied in the affirmative.

Capt. Elwes hoped that local societies might be induced to co-operate for the discovery of flint implements, and the formulation of the results attained.

Mr. Osmund W. Jeffs, Secretary to the British Association Committee for the collection and Preservation of geological Photographs, said that the photographs collected would be placed in the Museum of Practical Geology, Jermyn Street, London. The first part of the collection, 800 photographs, had already been placed there. It was proposed to go on collecting, as many parts of the British Isles were quite unrepresented.

Mr. De Rance thought that it would be a good thing if each society would issue a circular and send it to other local societies, so that it might be known what photographs had been taken in each locality.

Mr. J. B. Murdoch (Glasgow) thought that in too many of their investigations Scotland was excluded. He mentioned, as an instance, the British Association Committee for recording the position, \&c., of erratic blocks of England, Wales and Ireland.

Some discussion arose on this point, in which Mr. De Rance, Mr. Sowerbutts and Mr. G. P. Hughes took part. Then the Chairman said that he believed Scotland had been omitted in that instance because the Royal Society of Edinburgh had been working at the subject before the formation of the British Association Committee.

Mr. Murdoch replied that it was true that a Boulder Committee had existed in Scotland, but its director, Mr. Milne Holme, was dead, and had been unable to get about the country for some time before his death. The eight yearly reports issued by his Committee were very valuable, but for some time the work had been practically at a standstill.

The Chairman remarked that in that case it was most desirable that Scotland should be included by the Erratic Blocks Committee.

Deemster Gill said that the boulders of the Isle of Man were being noted by the Isle of Man Natural History and Antiquarian Society.

Prof. Meldola moved, and Mr. Hopkinson seconded, a motion in favour of an application to the General Committee for a grant of $£ 30$ to enable the Corresponding Societies Committee to carry on its work. This was carried, and the meeting ended.

At the second meeting, on Tuesday, September 17, the Corresponding Societies Committee was represented by Dr. Garson (in the chair), Mr. Hopkinson, Mr. Symons, and Mr. T. V. Holmes (Secretary).

The Chairman said that it was usual at their second meeting to consider the recommendations from the various Sections respecting work in which it was thought the Corresponding Societies might usefully co-operate.

\section{Section $A$}

Mr. White Wallis, representing Section A, said that the Committees for investigating earth tremors and seismological phenomena in Japan had been merged into one, with the title of "Committee for Seismological Observations." The Committee for the application of photography to meteorology had been reappointed, and so had the Underground Temperature Committee. The Meteorological Photographs Committee was simply desirous to obtain photographs of lightning, rainbows, halos, $\mathrm{Ec}$

The Rev. J. O. Bevan inquired whether the meteorological work formerly carried on at Stonyhurst by Father Perry was still going on. Mr. Sowerbutts answered that it was, and Mr. White Wallis said that he would note the suggestion that they should communicate with Stonyhurst. He added, in answer to questions, that instruments for noting earth tremors were unaffected by vibrations from passing waggons, trains, \&.c. 
Section $C$.

Mr. A. S. Reid, representing Section C, stated that Mr. Osmund Jeffs had consented to retain the post of secretary to the ( IV. Watts had agreed to act as co-secretary during that time, and afterwards to become sole secretary. The Erratic Blocks Committee had altered its title so as to include Scotland.

Mr. Murdoch hoped that the Farth Tremors Committee might include Scotland in its sphere of action. It was then a purely English Committee.

Mr. M. B. Slater thought that an exchange of local geological photographs among the various Corresponding Societies would be a good thing. Some discussion then took place on the practical difficulties likely to arise from an interchange, such as the burden likely to be laid upon the shoulders of the amateur photographer, \&c. Mr. Hopkinson thought that copies should be obtainable at the Jermyn-street Museum at a small fixed charge, and Mr. Keid mentioned a plan suggested by Mr. (iray of Belfast. At that town a photographer had been appointed who received the negatives taken by various members of the local societies, and furnished as many copies as were required at a small fixed charge.

\section{Section E.}

Mr. Sowerbutts said that the Committee of Section $\mathrm{E}$ had asked the Council of the British Association to permit them to have a Committee for the purpose of making an inquiry into the condition of the teaching of geography in Great Britain in all schools, especially secondary schools, and to report next year. It was probable that the Corresponding Societies might be asked to furnish certain information, and he hoped their secretaries would reply as promptly as possible.

The Rev. J. O. Bevan thought that the statements made in the report of the Conference of Delegates at Nottingham, that in some county, unnamed, "children attending schools were not taught geography in any way," and that geography was absolutely ignored in secondary schools, were decidedly erroneous, though in some primary schools it was not taught except in connection with reading. The Royal (ieographical Society had instituted examinations in geography in secondary schools, and gave gold medals and other prizes.

\section{Section $H$}

Mr. Hartland said that he was there owing to the very sad bereavement sustained recently by $\mathrm{Mr}$. Brabrook, the Chairman of the Ethnographical Survey Committee, who was consequently unable to attend. The Ethnographical Survey was a matter in which the Corresponding Societies were especially capable of rendering valuable assistance. They had hitherto, however, met with but little response from the local societies. The work had so many branches that some of them could scarcely fail to interest their more active members. If the Committee obtained the grant for which they asked, they proposed to begin work in Cialway, and he hoped to report progress at the next meeting. $\mathrm{He}$ would be glad if meanwhile the Corresponding Societies would circulate their schedules, and bring the Survey under the notice of their members.

Mr. M. B. Slater mentioned the work done in the neighbourhood of Malton by a sub-committee, of which Dr. Colby was chairman; and Mr. Hartland remarked that the Malton Naturalists 'Seciety was one of those which had responded to their circular.

The Chairman noted the great variety of the work of the Ethnographical Survey, which included questions of physical characteristics, folk-lore, linguistic differences, place-names, traditions, \&c. Satisfactory work had been done around Ipswich.

Mr. Hartland wished also to mention the preservation of ancient monuments. He had just received a letter from the Secretary of a local committee in Pembrokeshire, mentioning the recent discorery there of some ancient stones and some pit dwellings.

Mr. Hopkinson thought that the measurements asked for were very elaborate, and the questions were considered inquisitorial. He was sure that a simpler system would be found to answer better in practice, as then more societies or persons would be found willing to undertake the work.

Mr. Hartland hoped that members who objected to the elaborate measurements would take up the subjects of dialect, folk-lore, or prehistoric monuments. Though they hoped to be able to obtain the elaborate measurements in some cases, they were glad to get such measurements as could be procured. They did not consider their standard as of universal obligation.

The Chairman wished to say a few words about another Committee, that concerned with the measurement of school children. Many schools had been doing good work in this way, but unfortunately there had been no uniform system, so that the results obtained at one school could not be compared with those at another. The Committee had drawn up a system which he hoped would prove acceptable to the various schools.

Dr. Brett (Hertfordshire) said that since the York meeting of the British Association, fifteen years ago, it had been his custon as a medical man to record the height, weight, colour of hair and eyes, \&c., of children. He had up to that time made about three thousand observations, but had not yet been able to put his records into shape.

The Rev. J. O. Bevan spoke of the desirability of expediting the archeological survey of the kingdom, which had been begun a few years ago. He was then at work at the map of Hereford. shire, which was nearly ready for publication. He was surprised that the work had not been taken up more energetically by properly qualified persons in the different districts.

\section{THE AFFILIATED SOCIETIES OF THE AMERICAN ASSOCIATION.}

A FEATURE of the meetings of the American Association for the Advancement of Science is the number of affiliated societies which meet at nearly the same time and place, though having no organic connection with it. One disadvantage of this is that the Sections of the Association do not get many of the important papers read before the affiliated societies ; in fact, these societies seem almost to take the place of the Sections, and they certainly tend to put the Association in a secondary position. As a large number of the papers were more of local than of general interest, we confine ourselves to a brief statement of the societies which met at Springfield during the recent meeting of the American Association, and of a few of the subjects considered.

The Society for the Promotion of Agricultural Science discussed several papers on spraying as a prevention of the attacks of various insect pests and fungi, and also on cereal culture in the United States. At the end of the proceedings, Mr. R. Lazenby was elected President of the Society.

The attention of the Association of Economic Entomologists was largely directed to the results of experimenting with insecticides, and the methods of placing the knowledge before all agriculturists. A resolution was passed asking the Massachusetts anthorities to support the work of the Gipsy Moth Commission. Another resolution was adopted asking that the publication of "Insect Life" by the Department of Agriculture be resumed. The officers for the ensuing year are: President, Prof. C. H. Fernald ; first vice-president, Prof. F. M. Webster : second, Prof. Herbert O. Ames ; secretary, C. L. Marlatt.

The session of the American Forestry Association was a very successful one. In the course of a short communication, Baron Herman pointed out that Germany has comparatively the most forests in well-regulated administration of all the countries of the world ; that is, one-fourth of its whole area is covered with them (all under long and careful management). There is scarcely one tree in the whole of the fatherland which is not known personally to a forest officer, and which has not been sown or planted with more or less great care and labour. The whole area of wooded land is almost equally divided between State, community, and private persons. And it is thought that this is a very good state of affairs, the commonwealth being in that way well interested in its parts as well as in the whole, in the affairs connected with the forest growth. This of course influences legislation, and although laws concerning the forests are not passed in the Reichstag, but in the Parliaments of the individual States, there is scarcely a part of Germany where one is allowed to cut down a forest, and not plant it again, without the permission of the Department of Forestry. The forests are managed by hundreds of forest officers, and these are educated at special colleges for forestry, there being no less than eleven in Germany. The theoretical study at these colleges lasts generally four years, not counting the time a young man has to spend in learning practical work in the woods. This comparatively long time a man wants, for his training show how very much the science of forestry has been developed in 